Atmos. Chem. Phys., 19, 12163-12174, 2019

https://doi.org/10.5194/acp-19-12163-2019

(C) Author(s) 2019. This work is distributed under

the Creative Commons Attribution 4.0 License.

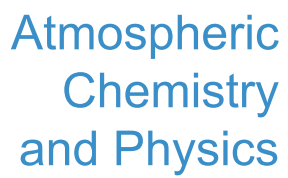

(c) (P)

\title{
Interactions between aerosol organic components and liquid water content during haze episodes in Beijing
}

\author{
Xiaoxiao $\mathrm{Li}^{1}$, Shaojie Song ${ }^{2}$, Wei Zhou ${ }^{1}$, Jiming Hao ${ }^{1}$, Douglas R. Worsnop ${ }^{3,4}$, and Jingkun Jiang ${ }^{1}$ \\ ${ }^{1}$ State Key Joint Laboratory of Environment Simulation and Pollution Control, School of Environment, \\ Tsinghua University, Beijing, 100084, China \\ ${ }^{2}$ School of Engineering and Applied Sciences, Harvard University, Cambridge, Massachusetts 02138, USA \\ ${ }^{3}$ Institute for Atmospheric and Earth System Research/Physics, Faculty of Science, University of Helsinki, Helsinki, Finland \\ ${ }^{4}$ Aerodyne Research Inc., Billerica, Massachusetts 01821, USA
}

Correspondence: J. Jiang (jiangjk@tsinghua.edu.cn)

Received: 1 April 2019 - Discussion started: 27 May 2019

Revised: 11 August 2019 - Accepted: 23 August 2019 - Published: 1 October 2019

\begin{abstract}
Aerosol liquid water (ALW) is ubiquitous in ambient aerosol and plays an important role in the formation of both aerosol organics and inorganics. To investigate the interactions between ALW and aerosol organics during haze formation and evolution, ALW was modelled based on longterm measurement of submicron aerosol composition in different seasons in Beijing. ALW contributed by aerosol in-

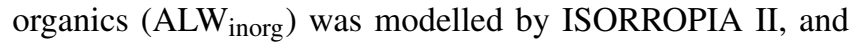
ALW contributed by organics $\left(\mathrm{ALW}_{\text {org }}\right)$ was estimated with $\kappa$-Köhler theory, where the real-time hygroscopicity parameter of the organics $\left(\kappa_{\text {org }}\right)$ was calculated from the real-time organic oxygen-to-carbon ratio $(\mathrm{O} / \mathrm{C})$. Overall particle hygroscopicity ( $\kappa_{\text {total }}$ ) was computed by weighting component hygroscopicity parameters based on their volume fractions in the mixture. We found that $\mathrm{ALW}_{\text {org }}$, which is often neglected in traditional ALW modelling, contributes a significant fraction (18\%-32\%) to the total ALW in Beijing. The $\mathrm{ALW}_{\text {org }}$ fraction is largest on the cleanest days when both the organic fraction and $\kappa_{\text {org }}$ are relatively high. The large variation in $\mathrm{O} / \mathrm{C}$, from 0.2 to 1.3 , indicates the wide variety of organic components. This emphasizes the necessity of using real-time $\kappa_{\text {org }}$, instead of fixed $\kappa_{\text {org }}$, to calculate ALW ${ }_{\text {org }}$ in Beijing. The significant variation in $\kappa_{\text {org }}$ (calculated from $\mathrm{O} / \mathrm{C}$ ), together with highly variable organic or inorganic volume fractions, leads to a wide range of $\kappa_{\text {total }}$ (between 0.20 and 0.45 ), which has a great impact on water uptake. The variation in organic $\mathrm{O} / \mathrm{C}$, or derived $\kappa_{\mathrm{org}}$, was found to be influenced by temperature $(T)$, ALW, and aerosol mass concentrations, among which $T$ and ALW both have promoting
\end{abstract}

effects on O/C. During high-ALW haze episodes, although the organic fraction decreases rapidly, $\mathrm{O} / \mathrm{C}$ and derived $\kappa_{\text {org }}$ increase with the increase in ALW, suggesting the formation of more soluble organics via heterogeneous uptake or aqueous processes. A positive feedback loop is thus formed: during high-ALW episodes, increasing $\kappa_{\text {org }}$, together with decreasing particle organic fraction (or increasing particle inorganic fraction), increases $\kappa_{\text {total }}$, and thus further promotes the ability of particles to uptake water.

\section{Introduction}

Aerosol liquid water (ALW) is a ubiquitous component of ambient aerosol and exerts great influences on aerosol physical and chemical properties, especially in regions with high relative humidity (RH) (Cheng et al., 2016, 2008; Covert et al., 1972; Ervens et al., 2014; Nguyen et al., 2016; Pilinis et al., 1989; Wu et al., 2018; Zheng et al., 2015). From the perspective of aerosol physical processes, ALW influences particle lifetime, optical properties, radiative forcing, and the ability of particles to deposit in the humid human respiratory tract (Andreae and Rosenfeld, 2008; Cheng et al., 2008; Covert et al., 1972; Löndahl et al., 2008). ALW also promotes partitioning of some of the inorganic gases and water-soluble organic gases to the condensed phase, thus directly increasing aerosol mass loadings (Asa-Awuku et al., 2010; Parikh et al., 2011). From the perspective of aerosol chemical processes, ALW can serve as a reactor for 
heterogeneous/aqueous reactions, facilitating the formation of both secondary inorganics (Cheng et al., 2016; Sievering et al., 1991; Wang et al., 2016) and organics (Carlton et al., 2009; Ervens et al., 2014; Song et al., 2019). As a result, understanding ALW content is critical in clarifying the formation and evolution of ambient aerosols as well as their impacts on air quality and climate, especially in urban cities like Beijing where severe haze events take place frequently with elevated RH (Sun et al., 2013; Zheng et al., 2015).

The interaction between ALW and aerosol chemical composition is a key issue for haze formation but remains uncertain, especially regarding the interaction between ALW and aerosol organics. Studies have demonstrated that secondary inorganic aerosol (SIA) and secondary organic aerosol (SOA) surpass primary species during haze formation in China (Huang et al., 2014; Sun et al., 2016; Zheng et al., 2016). SOA- or SIA-driven haze formation is widely observed to be associated with elevated relative humidity $(\mathrm{RH})$, especially in winter. In Beijing, as RH rises from below $40 \%$ to above $60 \%$, the following has been reported: (1) aerosol mass loadings increase significantly, (2) particle phase changes from solid/semisolid to liquid phase (Liu et al., 2017), (3) both sulfur and nitrogen oxidation ratios increase (Cheng et al., 2016; Sun et al., 2013; Zheng et al., 2015), (4) water-soluble inorganics increase faster than organics (Liu et al., 2015; Quan et al., 2015; Sun et al., 2013; Zheng et al., 2015). RH affects secondary species via heterogeneous uptake or aqueous processes. During haze episodes, gas-phase photochemical formation of SIA and SOA is largely suppressed by the weakened solar radiation (Zheng et al., 2015). Formation of SIA and SOA is thus suggested to be dominated by heterogeneous uptake or aqueous processes (Xu et al., 2017), which are largely dependent on ALW. Based on ALW measurements, previous studies have proposed positive feedback loops in which elevated RH increases particle concentration and particle inorganic fraction; increased particle concentration and inorganic fraction in turn increase the water uptake (Cheng et al., 2016; Liu et al., 2017; Wu et al., 2018). However, whether or how elevated ALW affects the evolution of SOA during haze episodes remains less understood than for SIA because of the complexity of SOA species.

Long-term data are needed to evaluate the amount of ALW and its interactions with aerosol organic compositions. So far, short-term ALW data in Beijing (Bian et al., 2014; Fajardo et al., 2016) have been collected by directly measuring size-resolved aerosol hygroscopic volume growth factors (VGFs) and particle size distributions using a hygroscopicity tandem differential mobility analyser (H-TDMA) (Rader and McMurry, 1986) or dry-ambient aerosol size spectrometer (DAASS) (Engelhart et al., 2011; Stanier et al., 2004). However, long-term measurements of ALW are rare because of the challenge in maintaining these instruments. Another approach to obtain ALW is to combine aerosol chemical composition measurements and model predictions. ALW con- tributed by inorganics can be modelled by inorganic thermodynamic equilibrium models, such as ISORROPIA II (Fountoukis and Nenes, 2007; Nenes et al., 1998, 1999), E-AIM (Clegg and Pitzer, 1992; Clegg et al., 1992), and SCAPE II (Kim et al., 1993a, b). Modelled inorganic water content is usually regarded as the total ALW because inorganic salts contribute to a large fraction of the total particle loading and the hygroscopicity of inorganic salts is much larger ( $\sim 6$ times) than that of organic species (Bian et al., 2014; Hennigan et al., 2008). Although this approximation provides reasonable ALW in many ambient conditions, it fails in some cases. Especially when organics contribute a dominant fraction to particle loading, large discrepancies arise between the modelled inorganic water and the actual ALW content (Fajardo et al., 2016). Therefore, it is important to take the organic contribution to ALW into consideration. Some specific models include the calculation of organic ALW, e.g. the Aerosol Diameter Dependent Equilibrium Model (ADDEM) (Topping et al., 2005a, b). However, application of such models is hindered by lack of long-term measurements of specific OA species.

Recent studies have proposed a method to predict total ALW using the non-refractory submicron particulate matter $\left(\mathrm{NR}-\mathrm{PM}_{1}\right.$, particle diameter between $40 \mathrm{~nm}$ and $\left.1 \mu \mathrm{m}\right)$ composition measured with the widely used aerosol mass spectrometer (AMS). The inorganic contribution to ALW $\left(\mathrm{ALW}_{\text {inorg }}\right)$ was modelled by ISORROPIA II; the organic contribution to ALW (ALW ${ }_{\text {org }}$ ) was estimated with $\kappa$-Köhler theory (Petters and Kreidenweis, 2007; Su et al., 2010). The total aerosol liquid water (ALW) is then the sum of $\mathrm{ALW}_{\text {inorg }}$ and $\mathrm{ALW}_{\text {org. }}$ ALW estimated by this method, which only requires aerosol chemical composition obtained from AMS measurements (Zhang et al., 2007), corresponds reasonably with measured ALW (the ratio of predicted ALW to measured ALW is 0.91, with $R^{2}=0.75$ ) (Guo et al., 2015). Thus, this method can be used to predict long-term ALW from aerosol chemical composition and to explore interactions between ALW and organic evolution during haze events.

In this study, long-term NR-PM $\mathrm{P}_{1}$ chemical composition measurement was used to predict ALW in Beijing during various seasons ( $292 \mathrm{~d}$ in 5 years). $\mathrm{ALW}_{\text {org }}$ and $\mathrm{ALW}_{\text {inorg }}$ were estimated using $\kappa$-Köhler theory and ISORROPIA II, respectively. A real-time organic hygroscopic parameter $\left(\kappa_{\text {org }}\right.$, calculated from the organic $\mathrm{O} / \mathrm{C}$ ratio) was used to estimate $\mathrm{ALW}_{\text {org }}$. The relationship between the total ALW and $\kappa_{\text {org }}$ was explored. Within this long-term dataset, 12 high-ALW haze episodes and eight low-ALW haze episodes were identified. Chemical evolution during high-ALW and low-ALW haze episodes was found to differ significantly. Positive feedback among organic hygroscopicity, organic volume fraction, overall particle hygroscopicity, and ALW is proposed to be a driving factor for severe haze formation in Beijing during high-ALW episodes. 


\section{Methodology}

\subsection{Long-term measurements of particle chemical composition}

Long-term measurements were carried out between December 2013 and August 2017 at an urban site located on the campus of Tsinghua University in Beijing. The monitoring site is located on the top floor of a four-storey building without other tall buildings nearby with detailed information provided elsewhere (Cai and Jiang, 2017; Cao et al., 2014; He et al., 2001). Data from $292 \mathrm{~d}$ were used, including 2-3 months' data from each of the four seasons (Table S1 in the Supplement). The average NR-PM $\mathrm{PM}_{1}$ mass concentrations from spring to winter were $81.1,54.2,63.9$, and $63.2 \mu \mathrm{g} \mathrm{m}^{-3}$, respectively. Note that $\mathrm{PM}_{2.5}$ concentrations in Beijing were decreasing during this period (http://www.bjepb.gov.cn/, last access: 20 September 2019).

Chemical composition of NR-PM 1 , including sulfate $\left(\mathrm{SO}_{4}^{2-}\right)$, nitrate $\left(\mathrm{NO}_{3}^{-}\right)$, ammonium $\left(\mathrm{NH}_{4}^{+}\right)$, chloride $\left(\mathrm{Cl}^{-}\right)$, and total organics (Org), was measured using a quadrupole aerosol chemical speciation monitor (Q-ACSM) ( $\mathrm{Ng}$ et al., 2011). The Q-ACSM was calibrated before each measurement following the procedure described by $\mathrm{Ng}$ et al., (2011). The meteorological conditions, including temperature $(T)$, relative humidity $(\mathrm{RH})$, and other routine meteorological parameters, were recorded by a meteorological station.

\subsection{Aerosol liquid water modelling}

$\mathrm{ALW}_{\text {inorg }}$ was modelled by ISORROPIA II using meteorological conditions and the Q-ACSM measured inorganic compositions. The model was carried out in "reverse" and "metastable" modes. Compared to the "stable" mode, metastable mode assumes that particles are always aqueous droplets, even at low RH. Although some earlier studies observed phase transitions of ambient particles, recent studies suggest that ambient aerosols tend to be in metastable states due to the coexistence of organic compounds that inhibit or cover up the deliquescence and efflorescence behaviour of inorganic compounds (Martin et al., 2008; Rood et al., 1989). The metastable mode predicts more water than predicted from the stable mode when RH is between $40 \%$ and $70 \%$, while it is similar to the latter when $\mathrm{RH}$ is above $70 \%$ or below $40 \%$ (Fig. S1 in the Supplement), consistent with a previous report (Song et al., 2018). In a few of the modelling results in summer and autumn, a high acid/base ratio caused some of the $\mathrm{NO}_{3}^{-}$and $\mathrm{Cl}^{-}$to enter the gas phase in the form of $\mathrm{HNO}_{3}$ and $\mathrm{HCl}$, resulting in disagreement between the output liquid-phase $\mathrm{NO}_{3}^{-}$and $\mathrm{Cl}^{-}$and the input aerosol-phase $\mathrm{NO}_{3}^{-}$and $\mathrm{Cl}^{-}$. These points were removed.

$\mathrm{ALW}_{\text {org }}$ was estimated using a simplified equation of $\kappa$ Köhler theory where Kelvin effect was neglected (Petters and
Kreidenweis, 2007) (Eq. 1),

$\mathrm{ALW}_{\text {org }}=V_{\text {org }} \kappa_{\text {org }} \frac{a_{\mathrm{w}}}{1-a_{\mathrm{w}}}$,

where $a_{\mathrm{w}}$ is the water activity and was assumed to be the same as RH (Bassett and Seinfeld, 1983) and $V_{\text {org }}$ is the volume concentration of organics measured by Q-ACSM (the density of organics was assumed to be $1.2 \mathrm{~g} \mathrm{~cm}^{-3}$ ). In previous studies, a fixed $\kappa_{\text {org }}$ in the range of $0.06-0.13$ was used for urban, urban downwind, and rural sites (Gunthe et al., 2011; Nguyen et al., 2016; Rose et al., 2011). However, the hygroscopicity of organics is highly variable and $\kappa_{\text {org }}$ can vary between 0 and 0.3 for different species (Lambe et al., 2011; Massoli et al., 2010). $\kappa_{\text {org }}$ was found to have a positive linear relationship with the organic $\mathrm{O} / \mathrm{C}$ ratio (Chang et al., 2010; Dick et al., 2000; Duplissy et al., 2011; Gunthe et al., 2011; Petters et al., 2009), which likely reflects combined effects of molecular weight, volatility, and surface activity (Nakao, 2017; Wang et al., 2019). Previous studies proposed several empirical methods to calculate $\kappa_{\text {org }}$ from $\mathrm{O} / \mathrm{C}$ derived from a series of chamber and field experiments (Chang et al., 2010; Duplissy et al., 2011; Jimenez et al., 2009; Lambe et al., 2011; Massoli et al., 2010). Comparing these methods (Table S2), Eq. (2) was used to calculate real-time $\kappa_{\text {org }}$ over a broad O/C range (0.05-1.42) (Lambe et al., 2011),

$\kappa_{\text {org }}=(0.18 \pm 0.04) \times \mathrm{O} / \mathrm{C}+0.03$,

where real-time $\mathrm{O} / \mathrm{C}$ was calculated from Q-ACSMmeasured $f_{44}$ (the fraction of $m / z 44$ fragment signal to total organic signal, $\mathrm{O} / \mathrm{C}=0.079+4.31 \times f_{44}$ ), which has been widely used to study the ageing process of OA species (Canagaratna et al., 2015; $\mathrm{Ng}$ et al., 2010).

The Zdanovskii-Stokes-Robinson (ZSR) mixing rule was used to calculate the total ALW. According to ZSR, the total water uptake into internally mixed particles is the sum of water content uptake by each pure component (Jing et al., 2018).

Particle hygroscopic volume growth factor (VGF) is the ratio of the volume of the wet particle to the corresponding particle volume at dry conditions. The size-independent VGF was calculated using Eq. (3),

$\mathrm{VGF}=\frac{\sum \frac{m_{i, \mathrm{ACSM}}}{\rho_{i}}+\left(\mathrm{ALW}_{\text {inorg }}+\mathrm{ALW}_{\text {org }}\right) / \rho_{\text {water }}}{\sum \frac{m_{i, \mathrm{ACSM}}}{\rho_{i}}}$,

where $m_{i, \mathrm{ACSM}}$ is the mass concentration of species " $i$ " measured by Q-ACSM. The densities were assumed to be 1.75, $1.75,1.75,1.52,1.2$, and $1.0 \mathrm{~g} \mathrm{~cm}^{-3}$ for sulfate, nitrate, ammonium, chloride, organics, and water, respectively (Salcedo et al., 2006).

Overall particle hygroscopicity $\left(\kappa_{\text {total }}\right)$ was calculated by weighting component hygroscopicity parameters by their volume fractions in the mixture (Dusek et al., 2010; Gunthe et al., 2009; Petters and Kreidenweis, 2007) (Eq. 4),

$\kappa_{\text {total }}=\kappa_{\text {inorg }} \cdot$ frac $_{\text {inorg }}+\kappa_{\text {org }} \cdot$ frac $_{\text {org }}$, 
where frac ${ }_{\text {inorg }}$ and $\mathrm{frac}_{\mathrm{org}}$ are the inorganic and organic volume fractions in NR-PM 1 , respectively. Inorganic species are mainly in the form of $\mathrm{NH}_{4} \mathrm{NO}_{3}, \mathrm{H}_{2} \mathrm{SO}_{4}, \mathrm{NH}_{4} \mathrm{HSO}_{4}$, and $\left(\mathrm{NH}_{4}\right)_{2} \mathrm{SO}_{4}$ (Liu et al., 2014); corresponding hygroscopic parameters were $0.68,0.68,0.56$, and 0.52 , respectively. As a result, an average value of 0.6 was used as the hygroscopicity parameter of the inorganic components $\left(\kappa_{\text {inorg }}\right)$, with the assumption that the relative abundance of $\mathrm{NH}_{4} \mathrm{NO}_{3}, \mathrm{H}_{2} \mathrm{SO}_{4}$, $\mathrm{NH}_{4} \mathrm{HSO}_{4}$, and $\left(\mathrm{NH}_{4}\right)_{2} \mathrm{SO}_{4}$ does not change significantly. Thus in our study, variation in $\kappa_{\text {total }}$ with RH only reflects changes in frac ${ }_{\text {org }}$ and $\kappa_{\text {org }}$.

\subsection{Haze episode identification}

The haze pollution in Beijing has shown a typical evolution pattern where a pollution episode usually starts with a clean day, then accumulates for 2-7d, and eventually disappears within 1-2d (Guo et al., 2014; Jia et al., 2008; Zheng et al., 2016). In this study, 22 haze episodes were identified (Table S3). Only episodes containing 4 or more than 4 calendar days were taken into consideration. The haze episodes were further classified according to ALW volume fraction, that is, the ratio of ALW volume to the wet particle total volume $\left(\mathrm{ALW}\right.$ volume fraction $\left.=V_{\mathrm{ALW}} /\left(V_{\mathrm{ALW}}+V_{\mathrm{NR}-\mathrm{PM}_{1}}\right)\right)$. A total of 12 were distinguished as high-ALW haze episodes (ALW volume fraction $>0.3$ for at least $50 \%$ of the haze period), while eight were distinguished as low-ALW haze episodes. All 20 distinguished episodes were associated with growing $\mathrm{RH}$; the other two with irregular RH variations were classified as undefined. Average NR-PM ${ }_{1}$ mass concentrations for the high-ALW and low-ALW episodes were 100.8 and $76.2 \mu \mathrm{g} \mathrm{m}^{-3}$, respectively.

The relative daily increments of frac ${ }_{\mathrm{org}}, \kappa_{\mathrm{org}}, \kappa_{\mathrm{org}} \cdot \mathrm{frac}_{\mathrm{org}}$ (indicates the contribution of organics to $\kappa_{\text {total }}$, and $\kappa_{\text {total }}$ during the classified 12 high-ALW haze episodes and eight lowALW haze episodes were averaged separately. Daily increments were used, rather than hourly increments, to avoid the impact of diurnal variability. The first and last days of the episodes were not included in the analysis as they were usually clean days, so that the chemical evolution was different from the hazy days. To minimize the influence of transport or large local primary emissions, the relative $\kappa_{\text {org }}$ daily increments of more than $40 \%$ were not included in further analysis.

\section{Results and discussion}

\subsection{Aerosol liquid water contributed by organics}

The contribution of $\mathrm{ALW}_{\text {org }}$ to $\mathrm{ALW}$ is the highest when $\mathrm{NR}_{-} \mathrm{PM}_{1}$ mass concentrations are below $25 \mu \mathrm{g} \mathrm{m}^{-3}$. In this low mass loading, $\mathrm{ALW}_{\text {org }} / \mathrm{ALW}$ varies widely between $\sim 10 \%$ and $\sim 80 \%$, with an average of $32 \%$ (Fig. 1a). The high $\mathrm{ALW}_{\text {org }} / \mathrm{ALW}$ in low aerosol mass concentrations can be explained by high organics/NR- $\mathrm{PM}_{1}$ mass fractions
$(57 \pm 15 \%)$ (as shown in Fig. 1b) and high $\kappa_{\text {org }}$ (as shown in Fig. 2). The striking variability in $A L W_{\text {org }} / A L W$ is the result of highly variable chemical compositions during clean days. In addition, higher uncertainties in NR-PM $\mathrm{PM}_{1}$ measurements of low NR-PM 1 loadings and in ALW modelling at low RH may also contribute to the large variability. High $\mathrm{ALW}_{\text {org }} / \mathrm{ALW}$ in low aerosol mass concentrations is consistent with previous studies (Dick et al., 2000; Fajardo et al., 2016). Those studies showed that modelled ALW $_{\text {inorg }}$ was much lower than measured total ALW under low aerosol mass loadings in Beijing (Fajardo et al., 2016) and that $\mathrm{ALW}_{\text {org }}$ was comparable to $\mathrm{ALW}_{\text {inorg }}$ in low $\mathrm{RH}$ (Dick et al., 2000).

As NR-PM $M_{1}$ mass concentrations increase from below $25 \mu \mathrm{g} \mathrm{m}^{-3}$ to above $100 \mu \mathrm{g} \mathrm{m}^{-3}$, the average $\mathrm{ALW}_{\text {org }} / \mathrm{ALW}$ fraction decreases from an average of $32 \%$ to $18 \%$ in Beijing (Fig. 1a). This decrease is mainly caused by the decrease in organics/NR $-\mathrm{PM}_{1}$ mass fractions from an average of $57 \%$ to $34 \%$ (Fig. 1b), and the decrease in organic/NR-PM 1 correlates with elevated $\mathrm{RH}$, as indicated by the colour of the scattered points. Although organic concentration increases with rising RH and NR-PM $M_{1}$, the concentration of inorganic water-soluble salts increases even more, leading to a decreased fraction of organics. Variation in $\mathrm{ALW}_{\text {org }}$ / ALW narrows as NR-PM 1 mass concentration increases. During high aerosol concentration, the aerosols are aged and dominated by secondary species (Huang et al., 2014), while during low concentration, the origins of aerosol are more complex and variable. As a result, the chemical composition of NR-PM becomes more homogeneous with the increase in NR-PM ${ }_{1}$.

$\mathrm{ALW}_{\text {org }}$ calculated using the real-time $\kappa_{\text {org }}$ is much higher than that using a fixed $\kappa_{\text {org }}(0.08)$, which has often been used to represent the hygroscopicity of urban organic aerosols (Nguyen et al., 2016). However, $\kappa_{\text {org }}$ in Beijing varies remarkably between 0.06 and 0.26 , with an average of $0.16 \pm$ 0.04 , much higher than 0.08 . This higher $\kappa_{\text {org }}$ results in a higher $\mathrm{ALW}_{\text {org }}$ fraction (18\%-32\%) calculated in our study than predicted in previous ones (Nguyen et al., 2016; Wu et al., 2018). We note higher $\kappa_{\text {org }}$ could be introduced via the conversion from organic $\mathrm{O} / \mathrm{C}$ (Eq. 2), though $\kappa_{\text {org }}$ calculated from other parameterizations (Chang et al., 2010; Duplissy et al., 2011; Massoli et al., 2010; Peter et al., 2006; Raatikainen et al., 2010) is even higher than the one used here (Fig. S2). As shown in Table S2, the average $\kappa_{\text {org }}$ values calculated from other methods are $0.22 \pm 0.07$ (Chang et al., 2010), $0.19 \pm 0.06$ (Massoli et al., 2010), and $0.21 \pm 0.08$ (Duplissy et al., 2011; Jimenez et al., 2009). Also, based on previous reports that Q-ACSM can report higher $f_{44}$ values than the high-resolution time-of-flight aerosol mass spectrometer (HR-ToF-AMS) (Fröhlich et al., 2015) and that $f_{44}$ reported by Q-ACSM may be highly variable among different instruments (Crenn et al., 2015), there is a possibility that positive deviations and large uncertainties of $f_{44}$ were introduced via the Q-ACSM measurements. Despite these possibilities, the large variations in $\kappa_{\text {org }}$ emphasize the need to use 

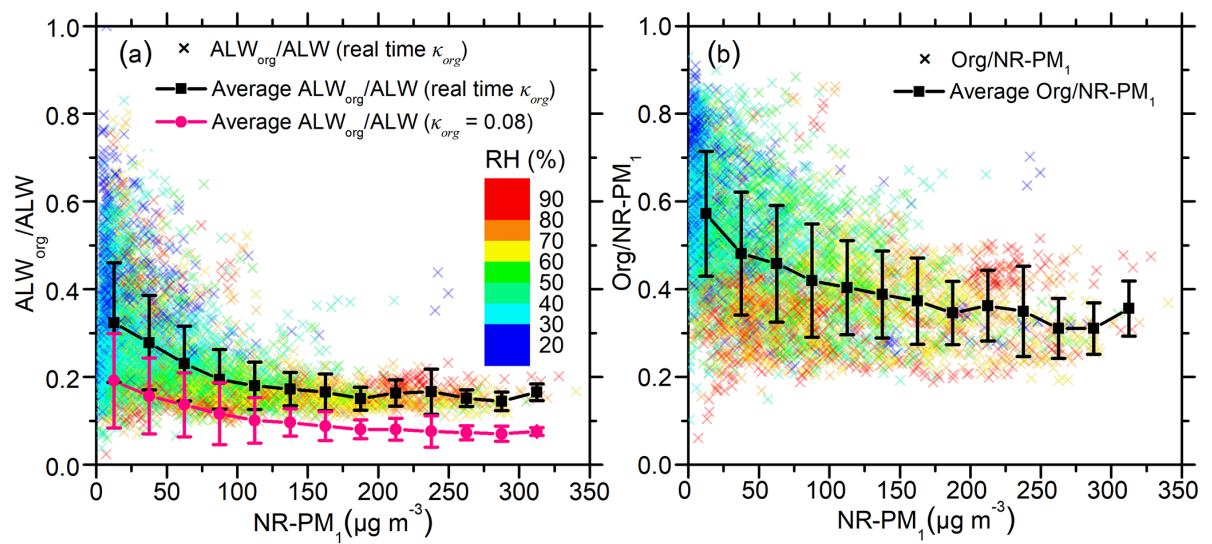

Figure 1. (a) The coloured scatter points represent the fraction of aerosol liquid water contributed by organics (ALW org $_{\text {ALW), }}$ which was

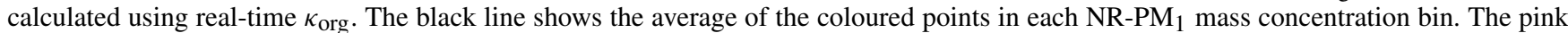
line is the average $\mathrm{ALW}_{\text {org }} / \mathrm{ALW}$ calculated using a fixed $\kappa_{\mathrm{org}}(0.08)$ in each NR-PM $\mathrm{P}_{1}$ mass concentration bin. (b) The coloured scatter points represent the organic mass fraction in non-refractory submicron aerosol $\left(\mathrm{NR}-\mathrm{PM}_{1}\right)$. The black line is the average of the coloured points in each NR-PM 1 mass concentration bin. All the scattered points in both figures are coloured with relative humidity (RH).
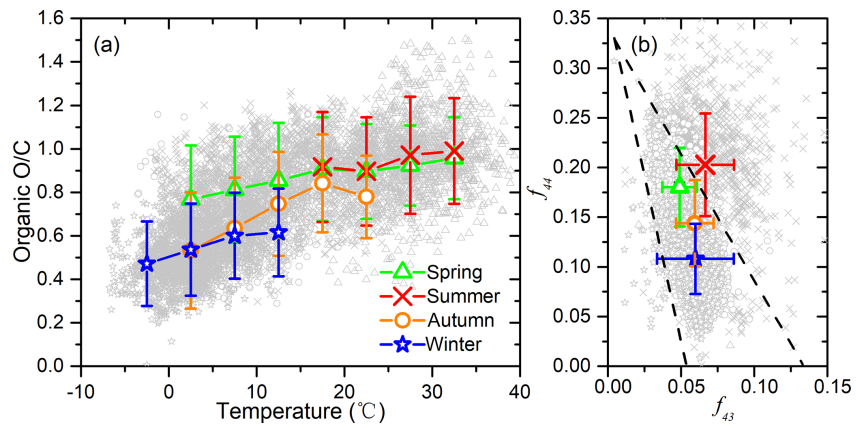

Figure 2. (a) $\mathrm{O} / \mathrm{C}$ ratio as a function of temperature in different seasons of Beijing; (b) triangle plot $\left(f_{44}\right.$ vs. $\left.f_{43}\right)$ measured by the Q-ACSM in different seasons of Beijing.

real-time $\kappa_{\text {org }}$ instead of a fixed value. When real-time $\kappa_{\text {org }}$ is not available, at least a localized average $\kappa_{\text {org }}$ for a given site should be considered.

\subsection{Influence of temperature, ALW, and NR-PM 1 mass concentrations on organic hygroscopicity}

Organic $\mathrm{O} / \mathrm{C}$ ratio and the derived organic hygroscopicity increase with an increase in the ambient temperature for all four seasons (Fig. 2). This positive correlation is more significant when $T$ is below $15^{\circ}$. For the different seasons, average $\mathrm{O} / \mathrm{C}$ ratios for summer, spring, autumn, and winter are 0.96 , $0.82,0.70$, and 0.55 , with corresponding average $T$ of 27.6, 14.6, 10.0, and $2.3^{\circ}$, respectively. Diurnally, organic O/C shows clear peaks at 14:00-16:00 LT, which matches the diurnal variation in $T$ well (Fig. S3). Similar diurnal changes of organic $\mathrm{O} / \mathrm{C}$ have been previously observed (Hu et al., 2016; Sun et al., 2016). The promoting effect of $T$ on $\mathrm{O} / \mathrm{C}$ can be attributed to multiple processes. On the one hand, $T$ often correlates with higher solar radiation and higher atmospheric oxidative capacity. On the other hand, higher $T$ accelerates gas phase and heterogeneous uptake or aqueous processes and thus increases $\mathrm{O} / \mathrm{C}$. In addition, higher $T$ promotes the partitioning of semi-volatile species (usually less oxidized than low-volatile species) from particle phase to gas phase, also resulting in an increase in particle organic $\mathrm{O} / \mathrm{C}$.

Figure 3 shows the influence of ALW and NR-PM $\mathrm{PM}_{1}$ mass concentration on organic $\mathrm{O} / \mathrm{C}$, and organic hygroscopicity. The cross-impact of $T$ on $\mathrm{O} / \mathrm{C}$ was separated by looking at the same colour in Fig. 3. When ALW volume fraction is high (above $0.2-0.3$ ), organic $\mathrm{O} / \mathrm{C}$ tends to increase with increasing ALW volume fraction; the increasing trend was most significant for spring and autumn, while less significant for winter (Fig. 3a, c, d). The area between the two black lines in Fig. 3a, c, d is dominated by the influence of ALW. Elevated ALW facilitates heterogeneous uptake or aqueous processes and promotes the formation of more oxidized organics, such as dicarboxylic acids, thus increasing $\mathrm{O} / \mathrm{C}$.

When ALW volume fraction is low (below 0.2-0.3), organic $\mathrm{O} / \mathrm{C}$ decreases with lower NR-PM 1 mass concentration, indicated by the size of the scattered points; this was observed in spring, autumn, and winter. One reason might be that at extremely low aerosol mass concentrations, new particle formation events frequently occur and smaller particles dominate size distribution (Cai et al., 2017; Guo et al., 2014). During formation and initial growth of new particles, extremely low-volatility organic compounds with the highest $\mathrm{O} / \mathrm{C}$ ratio dominate, while subsequent growth involves organics with higher volatility and a lower $\mathrm{O} / \mathrm{C}$ ratio (Donahue et al., 2013; Ehn et al., 2014). As a result, particle organic $\mathrm{O} / \mathrm{C}$ decreases with growth of aerosol mass concentration during new particle formation and growth events. Another possibility is that increased aerosol mass often coincides with 


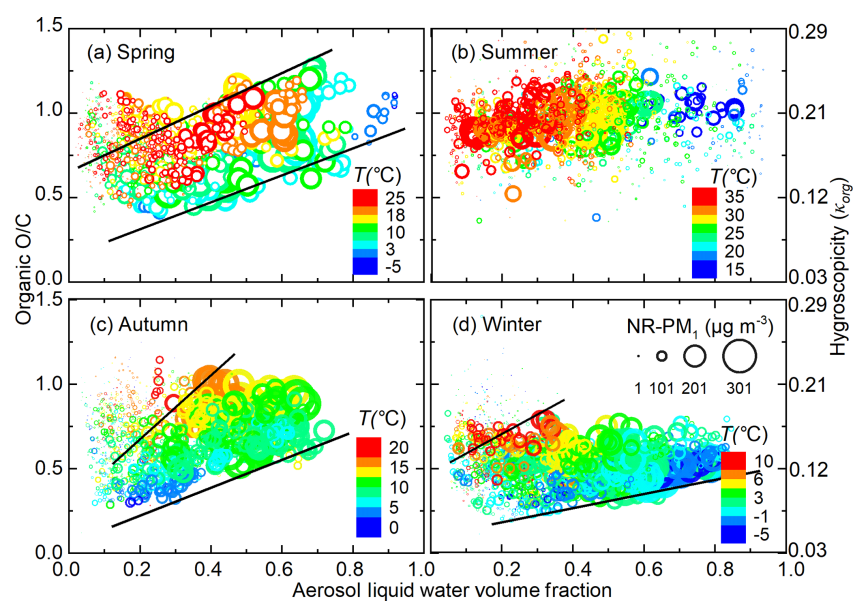

Figure 3. Variation in organic $\mathrm{O} / \mathrm{C}$ ratio (calculated from $\mathrm{Q}$ ACSM-measured $f_{44}$ ) as a function of aerosol liquid water (ALW) volume fraction in different seasons of Beijing. The size and colour of the points represent the corresponding NR-PM 1 mass concentration and ambient temperature, respectively. For spring, autumn, and winter, the areas between the two black lines represent the points less affected by the gas-particle partitioning under low aerosol mass loadings.

diminished solar radiation, which suppresses photochemistry and may decrease organic $\mathrm{O} / \mathrm{C}$. In addition, a fraction of the particles during clean periods are transported from less populated mountain areas. During such long-range transport, atmospheric oxidation can increase $\mathrm{O} / \mathrm{C}$. Low ALW volume fraction correlates with low NR-PM 1 mass loadings, which makes it look like organic $\mathrm{O} / \mathrm{C}$ is decreasing with increasing ALW volume fraction. Overall, the apparent opposite trends during high- and low-ALW-volume-fraction periods can actually be explained by a competition between the opposite impact of ALW and NR-PM 1 mass loadings on organic evolution. However, summer was an exception, where no obvious dependence of organic $\mathrm{O} / \mathrm{C}$ on ALW volume fraction or NR-PM ${ }_{1}$ mass concentration was observed.

The competing effects of ALW volume fractions and NR$\mathrm{PM}_{1}$ mass concentrations on organic $\mathrm{O} / \mathrm{C}$ were further confirmed by comparing organic evolution during the high- and low-ALW haze episodes. Figure 4 shows two typical haze episodes in Beijing, with more chemical and meteorological information given in Fig. S5. During the high-ALW episode, where ALW contributes $0.2-0.75$ to the total aerosol volume, organic $\mathrm{O} / \mathrm{C}$ increases with haze accumulation. The increase in nighttime $\mathrm{O} / \mathrm{C}$ is more striking than that in daytime, likely due to the more abundant ALW at night (see Fig. S4). On the contrary, during the low-ALW episode, where ALW volume fraction does not exceed $30 \%$, daytime organic $\mathrm{O} / \mathrm{C}$ decreases despite the increasing ALW and $T$; this indicates that the decrease in $\mathrm{O} / \mathrm{C}$ introduced by reduced photo-oxidation processes and gas-particle partitioning is larger than the $\mathrm{O} / \mathrm{C}$ increase from heterogeneous uptake or aqueous processes.
Nighttime $\mathrm{O} / \mathrm{C}$ remains relatively constant, suggesting that the promoting effect of heterogeneous uptake or aqueous processes on $\mathrm{O} / \mathrm{C}$ is comparable to the reducing effects on $\mathrm{O} / \mathrm{C}$.

\subsection{The influence of RH and particle hygroscopicity on particle hygroscopic volume growth factor}

Particle volume growth factor increases rapidly with $\mathrm{RH}$ and particle hygroscopicity (Fig. 5). When RH is less than $80 \%$, particle VGF increases slowly from 1 to 2.5 with rising $\mathrm{RH}$; when RH exceeds $80 \%$, VGF increases rapidly to above 5. This is generally consistent with previous studies (Bian et al., 2014). As shown in Fig. 5, significant variation in $\kappa_{\text {total }}$ also plays an important role in the change of water uptake. The dispersion of points in the vertical direction represents the influence of particle chemical compositions on ALW. For instance, when RH is fixed at $60 \%$, VGF increases from 1.2 to 1.9 when $\kappa_{\text {total }}$ increases from $\sim 0.20$ to $\sim 0.45$.

The seasonal variations also reflect a combined promoting effect of RH and $\kappa_{\text {total }}$ on VGF. The average VGFs for spring, summer, autumn, and winter are 1.4, 1.6, 1.3, and 1.3 , respectively. The highest VGF in summer is attributed to a combination of the higher frequency for high RH (red step line, compared to green, orange, and blue step line in Fig. $5 b$ ) and the relatively high particle hygroscopicity, $\kappa_{\text {total }}$ (0.35, compared to $0.38,0.30$, and 0.33 for other seasons).

A consequence of the high RH and high ALW is the higher overall particle hygroscopicity, $\kappa_{\text {total }}$, compared with that at the low RH (Fig. 5). Aerosols are dominated by less hygroscopic particles $\left(\kappa_{\text {total }}<0.3\right)$ for $\mathrm{RH}$ below $\sim 40 \%$ while aerosols are dominated by more hygroscopic particles $\left(\kappa_{\text {total }}>0.4\right)$ for RH above $\sim 80 \%$ (Fig. 5$)$. This suggests positive feedback between overall particle hygroscopicity and ALW. Higher $\kappa_{\text {total }}$ leads to higher ALW at a similar $\mathrm{RH}$ while higher ALW, or higher RH, in turn corresponds to higher $\kappa_{\text {total }}$.

\subsection{Interactions between organic evolution and particle hygroscopicity during high- and low-ALW episodes}

During high-ALW episodes, the organic volume fraction decreases and organic hygroscopicity increases substantially during the accumulation of pollution. The average frac $_{\text {org }}$ is 0.51 and the daily increment of frac $c_{\text {org }}$ is $-11 \%$ (Fig. 6). The negative frac ${ }_{\text {org }}$ increment indicates decreasing frac ${ }_{\text {org }}$, which reflects the larger increase in inorganic soluble compounds (sulfate, nitrate, ammonium, and chloride) compared to that of organics during haze episodes. The average $\kappa_{\mathrm{org}}$ is 0.165 and the relative daily increment of $\kappa_{\text {org }}$ is $8 \%$. The positive $\kappa_{\text {org }}$ increment during high-ALW episodes reflects increasing $\kappa_{\text {org }}$ due to the effect of heterogeneous uptake or aqueous processes. To sum up, although the organic fraction decreases during the high-ALW haze episodes, the organic hygroscopicity increases. As a result, the contribution 
(a) High-ALW haze episode

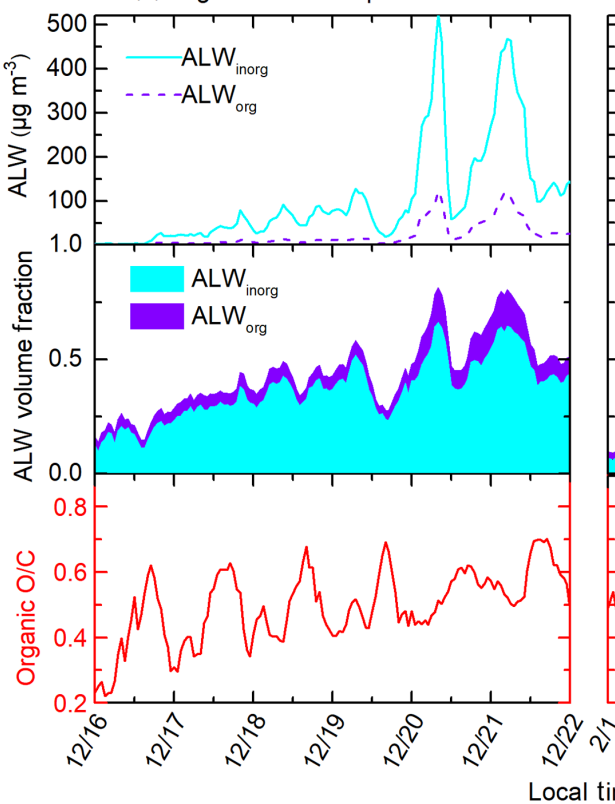

(b) Low-ALW haze episode

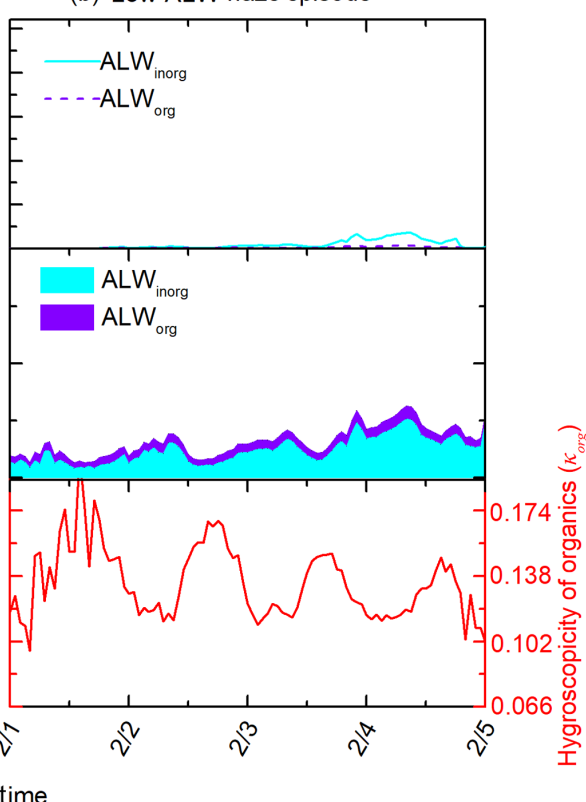

Figure 4. Variations in aerosol liquid water contributed by organics $\left(\mathrm{ALW}_{\mathrm{org}}\right)$, aerosol liquid water contributed by inorganics $\left(\mathrm{ALW} \mathrm{inorg}_{\mathrm{i}}\right)$, the volume fraction of total wet particle compositions, and organic O/C during (a) a typical high-ALW episode and (b) a typical low-ALW episode.

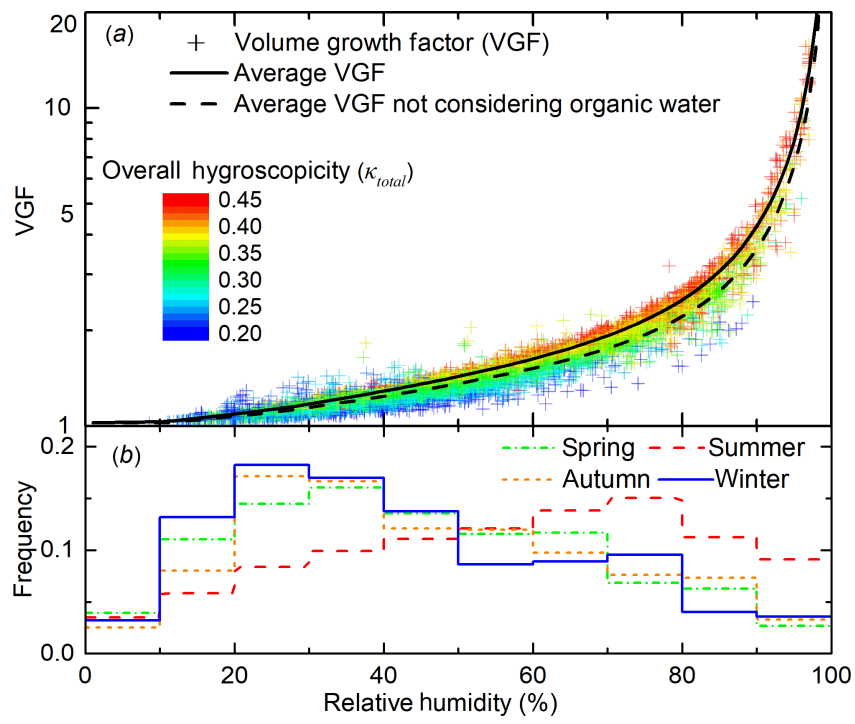

Figure 5. (a) Volume growth factor (VGF, scattered points, calculated by Eq. 3) from the four seasons as a function of relative humidity (RH). The points are coloured by overall particle hygroscopicity $\left(\kappa_{\text {total }}\right)$ calculated from aerosol bulk composition (Eq. 4). The black line is the averaged VGF at a different RH. Black dashed line is the average VGF without considering organic water. (b) RH frequency during four seasons is expressed as a step line.

of $\mathrm{ALW}_{\text {org }}$ to total ALW does not decrease as fast as the decrease in organic fraction.
During low-ALW episodes, the decrease in organic volume fraction is slower than that during high-ALW episodes, and organic hygroscopicity is relatively stable in the haze evolution process. The average frac $_{\text {org }}$ is 0.63 and the daily increment of frac $_{\text {org }}$ is $-4 \%$ (Fig. 6), of which both are higher than those in high-ALW episodes. This suggests that organics are still the dominating component as haze accumulated during low-ALW episodes. The average $\kappa_{\text {org }}$ is 0.152 and the relative daily increment of $\kappa_{\mathrm{org}}$ is $-1 \%$, both of which are lower than those in high-ALW episodes. The nearzero increment of $\kappa_{\text {org }}$ is a consequence of the competition between heterogeneous uptake or aqueous processes and other processes. To sum up, the effects of ALW on chemical compositions during low-ALW episodes are limited compared to high-ALW episodes.

As a consequence of the more significant changes in chemical composition during high-ALW episodes, the increase in particle hygroscopicity is larger for high-ALW episodes than for low-ALW episodes. The relative daily increments of frac ${ }_{\mathrm{org}} \cdot \kappa_{\mathrm{org}}$ during high-ALW and low-ALW episodes are $-4 \%$ and $-3 \%$, respectively (Fig. $6 \mathrm{c}$ ). These negative increments indicate the negative effect of the organic hygroscopic term on $\kappa_{\text {total }}$ during haze episodes. For high-ALW episodes, this means that the increase in organic hygroscopicity in high-ALW episodes does not compensate for the effect of decreasing organic fraction. However, the average daily increments of $\kappa_{\text {total }}$ during high-ALW and low-ALW haze episodes are $8 \%$ and $2 \%$, respectively (Fig. 6d). As $\kappa_{\text {inorg }}$ is fixed to 0.6 and the increment of fracinorg is opposite to 

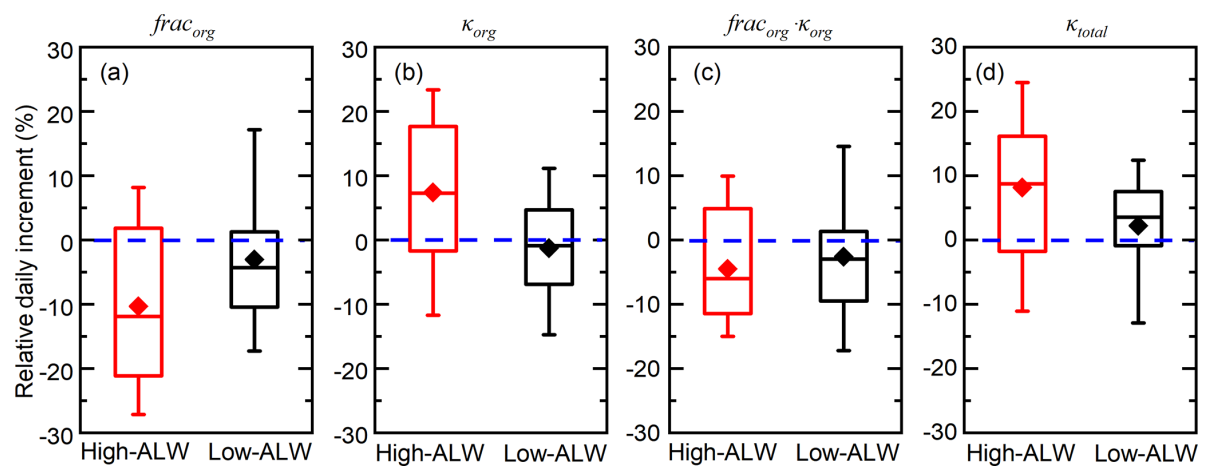

Figure 6. Episode-based relative day increment of organic hygroscopicity $\left(\kappa_{\mathrm{org}}\right)$, organic volume fraction (frac org $_{\text {) }}$, the hygroscopicity term contributed by organics $\left(\kappa_{\mathrm{org}} \cdot \mathrm{frac}_{\mathrm{org}}\right)$, and overall particle hygroscopicity $\left(\kappa_{\text {total }}\right)$ during high-ALW haze episodes and low-ALW haze episodes. The box plots represent the 10th, 25th, 50th, 75th, and 90th percentiles of the corresponding data. The rhombus represents the mean value of the corresponding data.

that of frac $_{\text {org }}$; the positive $\kappa_{\text {total }}$ increment is a result of the positive increment of the term frac $_{\text {inorg }} \cdot \kappa_{\text {inorg }}$.

The rapid decrease in frac $_{\text {org }}$ and increase in $\kappa_{\text {org }}$ during high-ALW episodes increase $\kappa_{\text {total}}$, which in turn promotes the ability of particles to uptake water, forming positive feedbacks with ALW, as the conceptual diagram shows (Fig. 7). The decrease in frac $_{\text {org }}$ or increase in fracinorg plays a dominating role while the increase in $\kappa_{\text {org }}$ plays a minor but non-negligible role in increasing $\kappa_{\text {total }}$. During low-ALW episodes, the positive feedbacks are weak or do not exist because both frac $\mathrm{org}_{\text {org }}$ and $\kappa_{\text {org }}$ do not change significantly.

There are other factors, not taken into consideration here, that might also affect ALW. These factors include the presence of crustal material or trace metals, detailed particle size distributions, interactions between inorganic and organic compounds, organic surfactants, and the particle phase state (Bian et al., 2014; Fountoukis and Nenes, 2007; Nakao, 2017; Ovadnevaite et al., 2017). As a result, we suggest that long-term measurements of ALW and $\kappa_{\text {org }}$ should be performed to test the results shown here and to establish a more reliable and accurate relationship between organic properties and ALW in the real atmosphere.

\section{Conclusion}

Our study emphasizes the need to include aerosol liquid water contributed by organics $\left(\mathrm{ALW}_{\text {org }}\right.$ ) in ALW modelling in Beijing, instead of only using the inorganic contribution to total ALW. The reason is that $\mathrm{ALW}_{\text {org }}$ contributes an average of $18 \%-32 \%$ to the total ALW in Beijing, according to our modelling results with ISORROPIA II, $\kappa$-Köhler theory, and the ZSR mixing rule. It is also necessary to use a real-time $\kappa_{\text {org }}$ to evaluate $\mathrm{ALW}_{\text {org }}$, since organic $\mathrm{O} / \mathrm{C}$, which has been shown in previous studies to have a linear relationship with $\kappa_{\mathrm{org}}$, varies from 0.2 to 1.3 in different seasons in Beijing. Using a fixed $\kappa_{\text {org }}(0.08)$ for typical urban areas underestimates $\mathrm{ALW}_{\text {org }}$ by a factor of $\sim 2$ in Beijing. When real-time

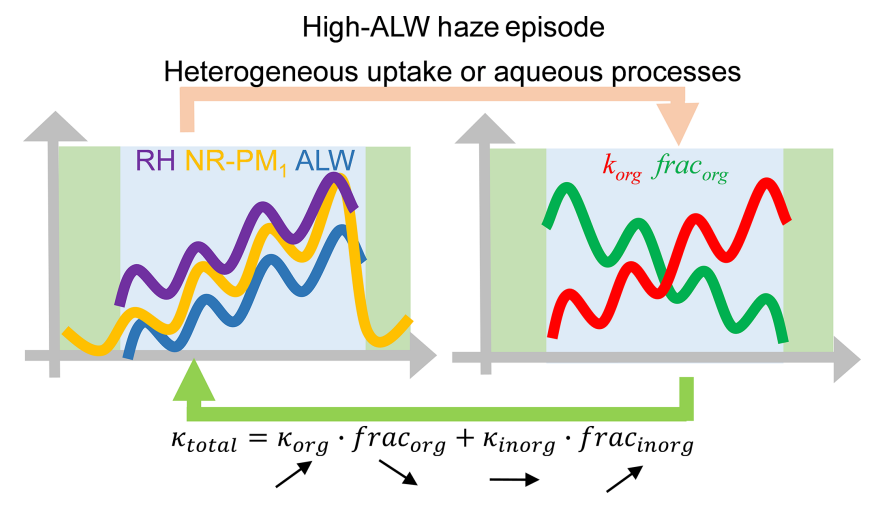

Figure 7. The positive feedback loops between aerosol liquid water and organic evolution during high-ALW haze episodes in Beijing.

$\kappa_{\text {org }}$ is not available, a localized average $\kappa_{\text {org }}$ should be used. $\mathrm{O} / \mathrm{C}$, or $\kappa_{\text {org }}$, generally increases with rising temperature and rising ALW in spring, autumn, and winter in Beijing.

Positive feedback loops were found between $\kappa_{\text {total }}$ (which was determined by frac $_{\mathrm{org}}$ and $\kappa_{\mathrm{org}}$, as $\kappa_{\text {inorg }}$ was assumed to be 0.6) and ALW during high-ALW episodes. During high-ALW haze episodes, RH, NR-PM 1 , and ALW increase rapidly. The strong heterogeneous uptake and aqueous processes lead to a rapid decrease in frac ${ }_{\text {org }}$ and an increase in $\kappa_{\text {org }}$. These variations increase $\kappa_{\text {total }}$, thus further promoting the uptake of water and forming positive feedbacks. These positive feedbacks were much weaker in low-ALW episodes. The positive feedback loop between chemical composition evolution (mainly indicated by $\mathrm{frac}_{\text {org }}$ and $\kappa_{\mathrm{org}}$ ) and ALW during high-ALW episodes is a driver for the severe haze episodes in Beijing.

Data availability. Data in this article are available upon request to the corresponding author (jiangjk@tsinghua.edu.cn). 
Supplement. The supplement related to this article is available online at: https://doi.org/10.5194/acp-19-12163-2019-supplement.

Author contributions. XL and JJ designed the study. WZ and XL performed the Q-ACSM field measurements. XL, SS, and JJ analysed the data with contributions from other co-authors. XL wrote the paper with contributions from other co-authors.

Competing interests. The authors declare that they have no conflict of interest.

Financial support. This research has been supported by the National Key R\&D Program of China (grant no. 2016YFC0200102) and the National Science Foundation of China (grant no. 91643201)

Review statement. This paper was edited by Aijun Ding and reviewed by two anonymous referees.

\section{References}

Andreae, M. O. and Rosenfeld, D.: Aerosol-cloud-precipitation interactions. Part 1. The nature and sources of cloud-active aerosols, Earth-Sci. Rev., 89, 13-41, 2008.

Asa-Awuku, A., Nenes, A., Gao, S., Flagan, R. C., and Seinfeld, J. H.: Water-soluble SOA from Alkene ozonolysis: composition and droplet activation kinetics inferences from analysis of CCN activity, Atmos. Chem. Phys., 10, 1585-1597, https://doi.org/10.5194/acp-10-1585-2010, 2010.

Bassett, M. and Seinfeld, J. H.: Atmospheric equilibrium model of sulfate and nitrate aerosols, Atmos. Environ., 17, 2237-2252, https://doi.org/10.1016/0004-6981(83)90221-4, 1983.

Bian, Y. X., Zhao, C. S., Ma, N., Chen, J., and Xu, W. Y.: A study of aerosol liquid water content based on hygroscopicity measurements at high relative humidity in the North China Plain, Atmos. Chem. Phys., 14, 6417-6426, https://doi.org/10.5194/acp14-6417-2014, 2014.

Cai, R. and Jiang, J.: A new balance formula to estimate new particle formation rate: reevaluating the effect of coagulation scavenging, Atmos. Chem. Phys., 17, 12659-12675, https://doi.org/10.5194/acp-17-12659-2017, 2017.

Cai, R., Yang, D., Fu, Y., Wang, X., Li, X., Ma, Y., Hao, J., Zheng, J., and Jiang, J.: Aerosol surface area concentration: a governing factor in new particle formation in Beijing, Atmos. Chem. Phys., 17, 12327-12340, https://doi.org/10.5194/acp-17-123272017, 2017.

Canagaratna, M. R., Jimenez, J. L., Kroll, J. H., Chen, Q., Kessler, S. H., Massoli, P., Hildebrandt Ruiz, L., Fortner, E., Williams, L. R., Wilson, K. R., Surratt, J. D., Donahue, N. M., Jayne, J. T., and Worsnop, D. R.: Elemental ratio measurements of organic compounds using aerosol mass spectrometry: characterization, improved calibration, and implications, Atmos. Chem. Phys., 15, 253-272, https://doi.org/10.5194/acp-15-253-2015, 2015.
Cao, C., Jiang, W., Wang, B., Fang, J., Lang, J., Tian, G., Jiang, J., and Zhu, T. F.: Inhalable microorganisms in Beijing's $\mathrm{PM}_{2.5}$ and $\mathrm{PM}_{10}$ pollutants during a severe smog event, Environ. Sci. Technol., 48, 1499-1507, 2014.

Carlton, A. G., Wiedinmyer, C., and Kroll, J. H.: A review of Secondary Organic Aerosol (SOA) formation from isoprene, Atmos. Chem. Phys., 9, 4987-5005, https://doi.org/10.5194/acp-9-49872009, 2009.

Chang, R. Y.-W., Slowik, J. G., Shantz, N. C., Vlasenko, A., Liggio, J., Sjostedt, S. J., Leaitch, W. R., and Abbatt, J. P. D.: The hygroscopicity parameter $(\kappa)$ of ambient organic aerosol at a field site subject to biogenic and anthropogenic influences: relationship to degree of aerosol oxidation, Atmos. Chem. Phys., 10, 5047-5064, https://doi.org/10.5194/acp-10-5047-2010, 2010.

Cheng, Y., Zheng, G., Wei, C., Mu, Q., Zheng, B., Wang, Z., Gao, M., Zhang, Q., He, K., Carmichael, G., Pöschl, U., and Su, H.: Reactive nitrogen chemistry in aerosol water as a source of sulfate during haze events in China, Science Advances, 2, e1601530, 10.1126/sciadv.1601530, 2016.

Cheng, Y. F., Wiedensohler, A., Eichler, H., Heintzenberg, J., Tesche, M., Ansmann, A., Wendisch, M., Su, H., Althausen, D., Herrmann, H., Gnauk, T., Brueggemann, E., Hu, M., and Zhang, Y. H.: Relative humidity dependence of aerosol optical properties and direct radiative forcing in the surface boundary layer at Xinken in Pearl River Delta of China: An observation based numerical study, Atmos. Environ., 42, 6373-6397, https://doi.org/10.1016/j.atmosenv.2008.04.009, 2008.

Clegg, S. L. and Pitzer, K. S.: Thermodynamics of multicomponent, miscible, ionic solutions: generalized equations for symmetrical electrolytes, J. Phys. Chem., 96, 3513-3520, 1992.

Clegg, S. L., Pitzer, K. S., and Brimblecombe, P.: Thermodynamics of multicomponent, miscible, ionic solutions. Mixtures including unsymmetrical electrolytes, J. Phys. Chem., 96, 9470-9479, 1992.

Covert, D. S., Charlson, R. J., and Ahlquist, N. C.: A study of the relationship of chemical composition and humidity to light scattering by aerosols, J. Appl. Meteorol., 11, 968-976, https://doi.org/10.1175/15200450(1972)011<0968:asotro>2.0.co;2, 1972.

Crenn, V., Sciare, J., Croteau, P. L., Verlhac, S., Fröhlich, R., Belis, C. A., Aas, W., Äijälä, M., Alastuey, A., Artiñano, B., Baisnée, D., Bonnaire, N., Bressi, M., Canagaratna, M., Canonaco, F., Carbone, C., Cavalli, F., Coz, E., Cubison, M. J., Esser-Gietl, J. K., Green, D. C., Gros, V., Heikkinen, L., Herrmann, H., Lunder, C., Minguillón, M. C., Močnik, G., O’Dowd, C. D., Ovadnevaite, J., Petit, J.-E., Petralia, E., Poulain, L., Priestman, M., Riffault, V., Ripoll, A., Sarda-Estève, R., Slowik, J. G., Setyan, A., Wiedensohler, A., Baltensperger, U., Prévôt, A. S. H., Jayne, J. T., and Favez, O.: ACTRIS ACSM intercomparison - Part 1: Reproducibility of concentration and fragment results from 13 individual Quadrupole Aerosol Chemical Speciation Monitors (Q-ACSM) and consistency with co-located instruments, Atmos. Meas. Tech., 8, 5063-5087, https://doi.org/10.5194/amt-8-50632015, 2015.

Dick, W. D., Saxena, P., and McMurry, P. H.: Estimation of water uptake by organic compounds in submicron aerosols measured during the Southeastern Aerosol and Visibility Study, J. Geophys. Res.-Atmos., 105, 1471-1479, 2000. 
Donahue, N. M., Ortega, I. K., Chuang, W., Riipinen, I., Riccobono, F., Schobesberger, S., Dommen, J., Baltensperger, U., Kulmala, M., Worsnop, D. R., and Vehkamaki, H.: How do organic vapors contribute to new-particle formation?, Faraday Discuss., 165, 91-104, https://doi.org/10.1039/c3fd00046j, 2013.

Duplissy, J., DeCarlo, P. F., Dommen, J., Alfarra, M. R., Metzger, A., Barmpadimos, I., Prevot, A. S. H., Weingartner, E., Tritscher, T., Gysel, M., Aiken, A. C., Jimenez, J. L., Canagaratna, M. R., Worsnop, D. R., Collins, D. R., Tomlinson, J., and Baltensperger, U.: Relating hygroscopicity and composition of organic aerosol particulate matter, Atmos. Chem. Phys., 11, 11551165, https://doi.org/10.5194/acp-11-1155-2011, 2011.

Dusek, U., Frank, G. P., Curtius, J., Drewnick, F., Schneider, J., Kuerten, A., Rose, D., Andreae, M. O., Borrmann, S., and Pöschl, U.: Enhanced organic mass fraction and decreased hygroscopicity of cloud condensation nuclei $(\mathrm{CCN})$ during new particle formation events, Geophys Res Lett, 37, L03804, https://doi.org/10.1029/2009g1040930, 2010.

Ehn, M., Thornton, J. A., Kleist, E., Sipila, M., Junninen, H., Pullinen, I., Springer, M., Rubach, F., Tillmann, R., Lee, B., Lopez-Hilfiker, F., Andres, S., Acir, I.-H., Rissanen, M., Jokinen, T., Schobesberger, S., Kangasluoma, J., Kontkanen, J., Nieminen, T., Kurtén, T., Nielsen, L. B., Jørgensen, S., Kjaergaard, H. G., Canagaratna, M., Dal Maso, M., Berndt, T., Petäjä, T., Wahner, A., Kerminen, V.-M., Kulmala, M., Worsnop, D. R., Wildt, J., and Mentel, T. F.: A large source of lowvolatility secondary organic aerosol, Nature, 506, 476-479, https://doi.org/10.1038/nature13032, 2014.

Engelhart, G. J., Hildebrandt, L., Kostenidou, E., Mihalopoulos, N., Donahue, N. M., and Pandis, S. N.: Water content of aged aerosol, Atmos. Chem. Phys., 11, 911-920, https://doi.org/10.5194/acp-11-911-2011, 2011.

Ervens, B., Sorooshian, A., Lim, Y. B., and Turpin, B. J.: Key parameters controlling $\mathrm{OH}$-initiated formation of secondary organic aerosol in the aqueous phase (aqSOA), J. Geophys. Res.Atmos., 119, 3997-4016, https://doi.org/10.1002/2013jd021021, 2014.

Fajardo, O. A., Jiang, J., and Hao, J.: Continuous Measurement of Ambient Aerosol Liquid Water Content in Beijing, Aerosol Air. Qual. Res., 16, 1152-1164, https://doi.org/10.4209/aaqr.2015.10.0579, 2016.

Fountoukis, C. and Nenes, A.: ISORROPIA II: a computationally efficient thermodynamic equilibrium model for $\mathrm{K}^{+}-$ $\mathrm{Ca}^{2+}-\mathrm{Mg}^{2+}-\mathrm{NH}_{4}^{+}-\mathrm{Na}^{+}-\mathrm{SO}_{4}^{2-}-\mathrm{NO}_{3}-\mathrm{Cl}-\mathrm{H}_{2} \mathrm{O}$ aerosols, Atmos. Chem. Phys., 7, 4639-4659, https://doi.org/10.5194/acp-74639-2007, 2007.

Fröhlich, R., Crenn, V., Setyan, A., Belis, C. A., Canonaco, F., Favez, O., Riffault, V., Slowik, J. G., Aas, W., Aijälä, M., Alastuey, A., Artiñano, B., Bonnaire, N., Bozzetti, C., Bressi, M., Carbone, C., Coz, E., Croteau, P. L., Cubison, M. J., EsserGietl, J. K., Green, D. C., Gros, V., Heikkinen, L., Herrmann, H., Jayne, J. T., Lunder, C. R., Minguillón, M. C., Močnik, G., O’Dowd, C. D., Ovadnevaite, J., Petralia, E., Poulain, L., Priestman, M., Ripoll, A., Sarda-Estève, R., Wiedensohler, A., Baltensperger, U., Sciare, J., and Prévôt, A. S. H.: ACTRIS ACSM intercomparison - Part 2: Intercomparison of ME-2 organic source apportionment results from 15 individual, co-located aerosol mass spectrometers, Atmos. Meas. Tech., 8, 2555-2576, https://doi.org/10.5194/amt-8-2555-2015, 2015.
Gunthe, S. S., King, S. M., Rose, D., Chen, Q., Roldin, P., Farmer, D. K., Jimenez, J. L., Artaxo, P., Andreae, M. O., Martin, S. T., and Pöschl, U.: Cloud condensation nuclei in pristine tropical rainforest air of Amazonia: size-resolved measurements and modeling of atmospheric aerosol composition and CCN activity, Atmos. Chem. Phys., 9, 7551-7575, https://doi.org/10.5194/acp9-7551-2009, 2009.

Gunthe, S. S., Rose, D., Su, H., Garland, R. M., Achtert, P., Nowak, A., Wiedensohler, A., Kuwata, M., Takegawa, N., Kondo, Y., Hu, M., Shao, M., Zhu, T., Andreae, M. O., and Pöschl, U.: Cloud condensation nuclei (CCN) from fresh and aged air pollution in the megacity region of Beijing, Atmos. Chem. Phys., 11, 1102311039, https://doi.org/10.5194/acp-11-11023-2011, 2011.

Guo, H., Xu, L., Bougiatioti, A., Cerully, K. M., Capps, S. L., Hite Jr., J. R., Carlton, A. G., Lee, S.-H., Bergin, M. H., Ng, N. L., Nenes, A., and Weber, R. J.: Fine-particle water and $\mathrm{pH}$ in the southeastern United States, Atmos. Chem. Phys., 15, 5211-5228, https://doi.org/10.5194/acp-15-5211-2015, 2015.

Guo, S., Hu, M., Zamora, M. L., Peng, J., Shang, D., Zheng, J., Du, Z., Wu, Z., Shao, M., and Zeng, L.: Elucidating severe urban haze formation in China, P. Natl. Acad. Sci. USA, 111, 17373-17378, 2014.

He, K., Yang, F., Ma, Y., Zhang, Q., Yao, X., Chan, C. K., Cadle, S., Chan, T., and Mulawa, P.: The characteristics of $\mathrm{PM}_{2.5}$ in Beijing, China, Atmos. Environ., 35, 4959-4970, 2001.

Hennigan, C. J., Bergin, M. H., Dibb, J. E., and Weber, R. $\mathrm{J}$.: Enhanced secondary organic aerosol formation due to water uptake by fine particles, Geophys. Res. Lett., 35, L18801, https://doi.org/10.1029/2008GL035046, 2008.

Hu, W., Hu, M., Hu, W., Jimenez, J. L., Yuan, B., Chen, W., Wang, M., Wu, Y., Chen, C., and Wang, Z.: Chemical composition, sources, and aging process of submicron aerosols in Beijing: Contrast between summer and winter, J. Geophys. Res.-Atmos., 121, 1955-1977, 2016.

Huang, R.-J., Zhang, Y., Bozzetti, C., Ho, K.-F., Cao, J.-J., Han, Y., Daellenbach, K. R., Slowik, J. G., Platt, S. M., and Canonaco, F.: High secondary aerosol contribution to particulate pollution during haze events in China, Nature, 514, 218-222, 2014.

Jia, Y., Rahn, K. A., He, K., Wen, T., and Wang, Y.: A novel technique for quantifying the regional component of urban aerosol solely from its sawtooth cycles, J. Geophys. Res., 113, D21309, https://doi.org/10.1029/2008jd010389, 2008.

Jimenez, J. L., Canagaratna, M. R., Donahue, N. M., Prevot, A. S. H., Zhang, Q., Kroll, J. H., DeCarlo, P. F., Allan, J. D., Coe, H., Ng, N. L., Aiken, A. C., Docherty, K. S., Ulbrich, I. M., Grieshop, A. P., Robinson, A. L., Duplissy, J., Smith, J. D., Wilson, K. R., Lanz, V. A., Hueglin, C., Sun, Y. L., Tian, J., Laaksonen, A., Raatikainen, T., Rautiainen, J., Vaattovaara, P., Ehn, M., Kulmala, M., Tomlinson, J. M., Collins, D. R., Cubison, M. J., Dunlea, E. J., Huffman, J. A., Onasch, T. B., Alfarra, M. R., Williams, P. I., Bower, K., Kondo, Y., Schneider, J., Drewnick, F., Borrmann, S., Weimer, S., Demerjian, K., Salcedo, D., Cottrell, L., Griffin, R., Takami, A., Miyoshi, T., Hatakeyama, S., Shimono, A., Sun, J. Y., Zhang, Y. M., Dzepina, K., Kimmel, J. R., Sueper, D., Jayne, J. T., Herndon, S. C., Trimborn, A. M., Williams, L. R., Wood, E. C., Middlebrook, A. M., Kolb, C. E., Baltensperger, U., and Worsnop, D. R.: Evolution of Organic Aerosols in the Atmosphere, Science, 326, 1525-1529, https://doi.org/10.1126/science.1180353, 2009. 
Jing, B., Wang, Z., Tan, F., Guo, Y., Tong, S., Wang, W., Zhang, Y., and Ge, M.: Hygroscopic behavior of atmospheric aerosols containing nitrate salts and water-soluble organic acids, Atmos. Chem. Phys., 18, 5115-5127, https://doi.org/10.5194/acp18-5115-2018, 2018.

Kim, Y. P., Seinfeld, J. H., and Saxena, P.: Atmospheric gas-aerosol equilibrium I. Thermodynamic model, Aerosol Sci. Tech., 19, 157-181, 1993a.

Kim, Y. P., Seinfeld, J. H., and Saxena, P.: Atmospheric gas-aerosol equilibrium II. Analysis of common approximations and activity coefficient calculation methods, Aerosol Sci Tech, 19, 182-198, $1993 b$.

Lambe, A. T., Onasch, T. B., Massoli, P., Croasdale, D. R., Wright, J. P., Ahern, A. T., Williams, L. R., Worsnop, D. R., Brune, W. H., and Davidovits, P.: Laboratory studies of the chemical composition and cloud condensation nuclei $(\mathrm{CCN})$ activity of secondary organic aerosol (SOA) and oxidized primary organic aerosol (OPOA), Atmos. Chem. Phys., 11, 8913-8928, https://doi.org/10.5194/acp-11-8913-2011, 2011.

Liu, H. J., Zhao, C. S., Nekat, B., Ma, N., Wiedensohler, A., van Pinxteren, D., Spindler, G., Müller, K., and Herrmann, H.: Aerosol hygroscopicity derived from size-segregated chemical composition and its parameterization in the North China Plain, Atmos. Chem. Phys., 14, 2525-2539, https://doi.org/10.5194/acp-14-2525-2014, 2014.

Liu, X. G., Sun, K., Qu, Y., Hu, M., Sun, Y. L., Zhang, F., and Zhang, Y. H.: Secondary Formation of Sulfate and Nitrate during a Haze Episode in Megacity Beijing, China, Aerosol Air Qual. Res., 15, 2246-2257, https://doi.org/10.4209/aaqr.2014.12.0321, 2015.

Liu, Y., Wu, Z., Wang, Y., Xiao, Y., Gu, F., Zheng, J., Tan, T., Shang, D., Wu, Y., Zeng, L., Hu, M., Bateman, A. P., and Martin, S. T.: Submicrometer Particles Are in the Liquid State during Heavy Haze Episodes in the Urban Atmosphere of Beijing, China, Environ. Sci. Tech. Let., 4, 427-432, https://doi.org/10.1021/acs.estlett.7b00352, 2017.

Löndahl, J., Pagels, J., Boman, C., Swietlicki, E., Massling, A., Rissler, J., Blomberg, A., Bohgard, M., and Sandström, T.: Deposition of biomass combustion aerosol particles in the human respiratory tract, Inhal. Toxicol., 20, 923-933, 2008.

Martin, S. T., Rosenoern, T., Chen, Q., and Collins, D. R.: Phase changes of ambient particles in the Southern Great Plains of Oklahoma, Geophys. Res. Lett., 35, L22801, https://doi.org/10.1029/2008GL035650, 2008.

Massoli, P., Lambe, A., Ahern, A., Williams, L., Ehn, M., Mikkilä, J., Canagaratna, M., Brune, W., Onasch, T., Jayne, J., Petäjä, T., Kulmala, M., Laaksonen, A., Kolb, C. E., Davidovits, P., and Worsnop, D. R.: Relationship between aerosol oxidation level and hygroscopic properties of laboratory generated secondary organic aerosol (SOA) particles, Geophys. Res. Lett., 37, L24801, https://doi.org/10.1029/2010GL045258, 2010.

Nakao, S.: Why would apparent $\kappa$ linearly change with O/C? Assessing the Role of Volatility, Solubility, and Surface Activity of Organic Aerosols, Aerosol Sci. Tech., 51, 1377-1388, https://doi.org/10.1080/02786826.2017.1352082, 2017.

Nenes, A., Pandis, S. N., and Pilinis, C.: ISORROPIA: A new thermodynamic equilibrium model for multiphase multicomponent inorganic aerosols, Aquat. Geochem., 4, 123-152, 1998.
Nenes, A., Pandis, S. N., and Pilinis, C.: Continued development and testing of a new thermodynamic aerosol module for urban and regional air quality models, Atmos. Environ., 33, 15531560, 1999.

Ng, N. L., Canagaratna, M. R., Zhang, Q., Jimenez, J. L., Tian, J., Ulbrich, I. M., Kroll, J. H., Docherty, K. S., Chhabra, P. S., Bahreini, R., Murphy, S. M., Seinfeld, J. H., Hildebrandt, L., Donahue, N. M., DeCarlo, P. F., Lanz, V. A., Prévôt, A. S. H., Dinar, E., Rudich, Y., and Worsnop, D. R.: Organic aerosol components observed in Northern Hemispheric datasets from Aerosol Mass Spectrometry, Atmos. Chem. Phys., 10, 46254641, https://doi.org/10.5194/acp-10-4625-2010, 2010.

Ng, N. L., Herndon, S. C., Trimborn, A., Canagaratna, M. R., Croteau, P. L., Onasch, T. B., Sueper, D., Worsnop, D. R., Zhang, Q., Sun, Y. L., and Jayne, J. T.: An Aerosol Chemical Speciation Monitor (ACSM) for Routine Monitoring of the Composition and Mass Concentrations of Ambient Aerosol, Aerosol Sci. Tech., 45, 780-794, 2011.

Nguyen, T. K. V., Zhang, Q., Jimenez, J. L., Pike, M., and Carlton, A. G.: Liquid Water: Ubiquitous Contributor to Aerosol Mass, Environ. Sci. Tech. Let., 3, 257-263, https://doi.org/10.1021/acs.estlett.6b00167, 2016.

Ovadnevaite, J., Zuend, A., Laaksonen, A., Sanchez, K. J., Roberts, G., Ceburnis, D., Decesari, S., Rinaldi, M., Hodas, N., and Facchini, M. C.: Surface tension prevails over solute effect in organic-influenced cloud droplet activation, Nature, 546, 637641, 2017.

Parikh, H. M., Carlton, A. G., Vizuete, W., and Kamens, R. M.: Modeling secondary organic aerosol using a dynamic partitioning approach incorporating particle aqueous-phase chemistry, Atmos. Environ., 45, 1126-1137, 2011.

Peter, T., Marcolli, C., Spichtinger, P., Corti, T., Baker, M. B., and Koop, T.: When dry air is too humid, Science, 314, 1399-1402, 2006.

Petters, M. D. and Kreidenweis, S. M.: A single parameter representation of hygroscopic growth and cloud condensation nucleus activity, Atmos. Chem. Phys., 7, 1961-1971, https://doi.org/10.5194/acp-7-1961-2007, 2007.

Petters, M. D., Wex, H., Carrico, C. M., Hallbauer, E., Massling, A., McMeeking, G. R., Poulain, L., Wu, Z., Kreidenweis, S. M., and Stratmann, F.: Towards closing the gap between hygroscopic growth and activation for secondary organic aerosol - Part 2: Theoretical approaches, Atmos. Chem. Phys., 9, 39994009, https://doi.org/10.5194/acp-9-3999-2009, 2009.

Pilinis, C., Seinfeld, J. H., and Grosjean, D.: WATER-CONTENT OF ATMOSPHERIC AEROSOLS, Atmos. Environ., 23, 16011606, https://doi.org/10.1016/0004-6981(89)90419-8, 1989.

Quan, J., Liu, Q., Li, X., Gao, Y., Jia, X., Sheng, J., and Liu, Y.: Effect of heterogeneous aqueous reactions on the secondary formation of inorganic aerosols during haze events, Atmos. Environ., 122, 306-312, https://doi.org/10.1016/j.atmosenv.2015.09.068, 2015.

Raatikainen, T., Vaattovaara, P., Tiitta, P., Miettinen, P., Rautiainen, J., Ehn, M., Kulmala, M., Laaksonen, A., and Worsnop, D. R.: Physicochemical properties and origin of organic groups detected in boreal forest using an aerosol mass spectrometer, Atmos. Chem. Phys., 10, 2063-2077, https://doi.org/10.5194/acp10-2063-2010, 2010. 
Rader, D. and McMurry, P.: Application of the tandem differential mobility analyzer to studies of droplet growth or evaporation, J. Aerosol Sci., 17, 771-787, 1986.

Rood, M., Shaw, M., Larson, T., and Covert, D.: Ubiquitous nature of ambient metastable aerosol, Nature, 337, 537-539, 1989.

Rose, D., Gunthe, S. S., Su, H., Garland, R. M., Yang, H., Berghof, M., Cheng, Y. F., Wehner, B., Achtert, P., Nowak, A., Wiedensohler, A., Takegawa, N., Kondo, Y., Hu, M., Zhang, Y., Andreae, M. O., and Pöschl, U.: Cloud condensation nuclei in polluted air and biomass burning smoke near the megacity Guangzhou, China - Part 2: Size-resolved aerosol chemical composition, diurnal cycles, and externally mixed weakly CCN-active soot particles, Atmos. Chem. Phys., 11, 2817-2836, https://doi.org/10.5194/acp-11-2817-2011, 2011.

Salcedo, D., Onasch, T. B., Dzepina, K., Canagaratna, M. R., Zhang, Q., Huffman, J. A., DeCarlo, P. F., Jayne, J. T., Mortimer, P., Worsnop, D. R., Kolb, C. E., Johnson, K. S., Zuberi, B., Marr, L. C., Volkamer, R., Molina, L. T., Molina, M. J., Cardenas, B., Bernabé, R. M., Márquez, C., Gaffney, J. S., Marley, N. A., Laskin, A., Shutthanandan, V., Xie, Y., Brune, W., Lesher, R., Shirley, T., and Jimenez, J. L.: Characterization of ambient aerosols in Mexico City during the MCMA-2003 campaign with Aerosol Mass Spectrometry: results from the CENICA Supersite, Atmos. Chem. Phys., 6, 925-946, https://doi.org/10.5194/acp-6925-2006, 2006.

Sievering, H., Boatman, J., Galloway, J., Keene, W., Kim, Y., Luria, M., and Ray, J.: Heterogeneous sulfur conversion in sea-salt aerosol particles: the role of aerosol water content and size distribution, Atmos. Environ. A-Gen., 25, 1479-1487, 1991.

Song, S., Gao, M., Xu, W., Shao, J., Shi, G., Wang, S., Wang, Y., Sun, Y., and McElroy, M. B.: Fine-particle $\mathrm{pH}$ for Beijing winter haze as inferred from different thermodynamic equilibrium models, Atmos. Chem. Phys., 18, 7423-7438, https://doi.org/10.5194/acp-18-7423-2018, 2018.

Song, S., Gao, M., Xu, W., Sun, Y., Worsnop, D. R., Jayne, J. T., Zhang, Y., Zhu, L., Li, M., Zhou, Z., Cheng, C., Lv, Y., Wang, Y., Peng, W., Xu, X., Lin, N., Wang, Y., Wang, S., Munger, J. W., Jacob, D. J., and McElroy, M. B.: Possible heterogeneous chemistry of hydroxymethanesulfonate (HMS) in northern China winter haze, Atmos. Chem. Phys., 19, 1357-1371, https://doi.org/10.5194/acp-19-1357-2019, 2019.

Stanier, C. O., Khlystov, A. Y., Chan, W. R., Mandiro, M., and Pandis, S. N.: A Method for the In Situ Measurement of Fine Aerosol Water Content of Ambient Aerosols: The Dry-Ambient Aerosol Size Spectrometer (DAASS) Special Issue of Aerosol Science and Technology on Findings from the Fine Particulate Matter Supersites Program, Aerosol Sci. Tech., 38, 215-228, 2004.

Su, H., Rose, D., Cheng, Y. F., Gunthe, S. S., Massling, A., Stock, M., Wiedensohler, A., Andreae, M. O., and Pöschl, U.: Hygroscopicity distribution concept for measurement data analysis and modeling of aerosol particle mixing state with regard to hygroscopic growth and CCN activation, Atmos. Chem. Phys., 10, 7489-7503, https://doi.org/10.5194/acp-10-7489-2010, 2010.

Sun, Y., Du, W., Fu, P., Wang, Q., Li, J., Ge, X., Zhang, Q., Zhu, C., Ren, L., Xu, W., Zhao, J., Han, T., Worsnop, D. R., and Wang, Z.: Primary and secondary aerosols in Beijing in winter: sources, variations and processes, Atmos. Chem. Phys., 16, 8309-8329, https://doi.org/10.5194/acp-16-8309-2016, 2016.
Sun, Y. L., Wang, Z. F., Fu, P. Q., Jiang, Q., Yang, T., $\mathrm{Li}, \mathrm{J}$, and Ge, X. L.: The impact of relative humidity on aerosol composition and evolution processes during wintertime in Beijing, China, Atmos. Environ., 77, 927-934, https://doi.org/10.1016/j.atmosenv.2013.06.019, 2013.

Topping, D. O., McFiggans, G. B., and Coe, H.: A curved multicomponent aerosol hygroscopicity model framework: Part 1 - Inorganic compounds, Atmos. Chem. Phys., 5, 1205-1222, https://doi.org/10.5194/acp-5-1205-2005, 2005a.

Topping, D. O., McFiggans, G. B., and Coe, H.: A curved multicomponent aerosol hygroscopicity model framework: Part 2 - Including organic compounds, Atmos. Chem. Phys., 5, 1223-1242, https://doi.org/10.5194/acp-5-1223-2005, 2005b.

Wang, G., Zhang, R., Gomez, M. E., Yang, L., Zamora, M. L., Hu, M., Lin, Y., Peng, J., Guo, S., and Meng, J.: Persistent sulfate formation from London Fog to Chinese haze, P. Natl. Acad. Sci. USA, 113, 13630-13635, 2016.

Wang, J., Shilling, J. E., Liu, J., Zelenyuk, A., Bell, D. M., Petters, M. D., Thalman, R., Mei, F., Zaveri, R. A., and Zheng, G. Cloud droplet activation of secondary organic aerosol is mainly controlled by molecular weight, not water solubility, Atmos. Chem. Phys., 19, 941-954, https://doi.org/10.5194/acp-19-9412019, 2019.

Wu, Z., Wang, Y., Tan, T., Zhu, Y., Li, M., Shang, D., Wang, H., Lu, K., Guo, S., and Zeng, L.: Aerosol Liquid Water Driven by Anthropogenic Inorganic Salts: Implying Its Key Role in Haze Formation over the North China Plain, Environ. Sci. Tech. Let., $5,160-166,2018$.

Xu, W., Han, T., Du, W., Wang, Q., Chen, C., Zhao, J., Zhang, Y., Li, J., Fu, P., and Wang, Z.: Effects of Aqueous-Phase and Photochemical Processing on Secondary Organic Aerosol Formation and Evolution in Beijing, China, Environ. Sci. Technol., 51, 762770, 2017.

Zhang, Q., Jimenez, J. L., Canagaratna, M. R., Allan, J. D., Coe, H., Ulbrich, I., Alfarra, M. R., Takami, A., Middlebrook, A. M., Sun, Y. L., Dzepina, K., Dunlea, E., Docherty, K., DeCarlo, P. F., Salcedo, D., Onasch, T., Jayne, J. T., Miyoshi, T., Shimono, A., Hatakeyama, S., Takegawa, N., Kondo, Y., Schneider, J., Drewnick, F., Borrmann, S., Weimer, S., Demerjian, K., Williams, P., Bower, K., Bahreini, R., Cottrell, L., Griffin, R. J., Rautiainen, J., Sun, J. Y., Zhang, Y. M., and Worsnop, D. R.: Ubiquity and dominance of oxygenated species in organic aerosols in anthropogenically-influenced Northern Hemisphere midlatitudes, Geophys. Res. Lett., 34, L13801, https://doi.org/10.1029/2007GL029979, 2007.

Zheng, G., Duan, F., Ma, Y., Zhang, Q., Huang, T., Kimoto, T., Cheng, Y., Su, H., and He, K.: Episode-Based Evolution Pattern Analysis of Haze Pollution: Method Development and Results from Beijing, China, Environ. Sci. Technol., 50, 4632-4641, https://doi.org/10.1021/acs.est.5b05593, 2016.

Zheng, G. J., Duan, F. K., Su, H., Ma, Y. L., Cheng, Y., Zheng, B., Zhang, Q., Huang, T., Kimoto, T., Chang, D., Pöschl, U., Cheng, Y. F., and He, K. B.: Exploring the severe winter haze in Beijing: the impact of synoptic weather, regional transport and heterogeneous reactions, Atmos. Chem. Phys., 15, 2969-2983, https://doi.org/10.5194/acp-15-2969-2015, 2015. 